\title{
Accreditation and certification of hospital quality: different or similar?
}

\author{
R. M. Guerra Bretaña ${ }^{1, \psi}$, Y. A. Marín Álvarez ${ }^{2}$ \\ ${ }^{1}$ Cátedra de Calidad, Metrología y Normalización, Centro de Biomateriales, \\ Universidad de La Habana, Cuba \\ ${ }^{2}$ Grupo de Investigación COINDE, Politécnico Colombiano Jaime Isaza Cadavid, Medellín, Colombia
}

\begin{abstract}
The external evaluation and management of hospital quality are two intimately related aspects of the same phenomenon: the need to improve the quality of health services and provide confidence of this quality to all stakeholders. The objective of this study is to analyze the hospital accreditation programs and ISO 9001 quality management and certification schemes of health institutions, as well as to identify the benefits of each of them, their similarities and differences. Hospital accreditations and ISO 9001 certifications are important instruments to improve the health service quality and to give confidence to the society about the health care provider. Both guide management strategies to improve service quality and patient safety. They differ in some aspects: accreditation is based on the best practices of the quality of the medical assistance and have a more technical character. The ISO 9001 standard is more process oriented and constitutes a suitable framework for incorporating the requirements of hospital accreditation programs and existing international methodologies for risk management in health institutions.
\end{abstract}

Keywords - accreditation, certification ISO 9001, hospital quality.

\section{ACREDITACIÓN Y CERTIFICACIÓN DE CALIDAD HOSPITALARIA ¿DIFERENTES O SIMILARES?}

\footnotetext{
Resumen-La evaluación externa y la gestión de la calidad hospitalaria son dos aspectos íntimamente relacionados del mismo fenómeno: la necesidad de mejorar la calidad de los servicios de salud y brindar confianza de esta calidad a todas las partes interesadas. El objetivo de este estudio es analizar los programas de acreditación hospitalaria y los sistemas de gestión y certificación de calidad ISO 9001 de las instituciones sanitarias, así como identificar los beneficios de cada uno de ellos, sus similitudes y diferencias. Las acreditaciones hospitalarias y las certificaciones ISO 9001 son instrumentos importantes para mejorar la calidad del servicio de salud y para dar confianza a la sociedad sobre el proveedor de atención médica. Ambos guían las estrategias de gestión para mejorar la calidad del servicio y la seguridad del paciente. Difieren en algunos aspectos: la acreditación se basa en las mejores prácticas de la calidad de la asistencia médica y tiene un carácter más técnico. La norma ISO 9001 está más orientada al proceso y constituye un marco adecuado para incorporar los requisitos de los programas de acreditación hospitalaria y las metodologías internacionales existentes para la gestión del riesgo en las instituciones de salud.
}

Palabras clave-acreditación, certificación ISO 9001, calidad hospitalaria. 


\section{ACREDITAÇÃO E CERTIFICAÇÃO DA QUALIDADE HOSPITALAR ¿DIFERENTES OU SIMILARES?}

Resumo-A avaliação externa e a gestão da qualidade hospitalar são dois aspectos intimamente relacionados do mesmo fenómeno: a necessidade de melhorar a qualidade dos serviços de saúde e brindar confiança desta qualidade a todas as partes interessadas. O objetivo deste estudo é analisar os programas de acreditação hospitalar e os sistemas de gestão e certificação de qualidade ISO 9001 das instituições sanitárias, bem como identificar os benefícios da cada um deles, seus similitudes e diferenças. As acreditações hospitalares e as certificações ISO 9001 são instrumentos importantes para melhorar a qualidade do serviço de saúde e para dar confiança à sociedade sobre o provedor de atenção médica. Ambos guiam as estratégias de gestão para melhorar a qualidade do serviço e a segurança do paciente. Diferem em alguns aspectos: a acreditação baseia-se nas melhores práticas da qualidade da assistência médica e tem um carácter mais técnico. A norma ISO 9001 está mais orientada ao processo e constitui um marco adequado para incorporar os requisitos dos programas de acreditação hospitalar e as metodologias internacionais existentes para a gestão do risco nas instituições de saúde.

Palavras-chave — acreditação, certificação ISO 9001, qualidade hospitalar.

\section{INTRODUCTION}

A $\mathrm{t}$ present, activities aimed at guaranteeing and improving quality in the health sector are carried out in two closely related directions: external evaluation and internal quality management of health institutions. These trends have evolved following the changes that have occurred in the administration of health services, under the influence of the socio-economic environment.

According to Arce [1] in the 1950s and 1960s, immediately after the creation of the World Health Organization (WHO), the administration of health services focused essentially on planning. The health organization model, initiated in 1948 by the British National Health Service (NHS), was based on a governmental organization which, through the central planning instrument, identifies the needs of the population and allocates resource. In this type of organization, the health administrators are positioned at the top of the NHS.

In the 1980s, the growth of Social Security in European countries involved the splitting of the health sector into two functions: the financing function and the health care service function. This separation moved the location of the health administrators to the institutions providing the health care services. In this way the planning started to be exercised from the institutions and aimed for the efficient management of the activities involved. At this stage, the medical audit also emerges as a systematic evaluation performed by physicians, which compares the characteristics or quality of the care provided and observed with the ideal and desired quality, according to pre-established criteria and standards [2].

In the 1990s, notions of quality and responsibility in the delivery of health services were developed, as a basis for their efficacy and efficiency. In this conception, quality administration of health services is placed at the base of the system. Previously, since the 1970s, Donabedian [3] had raised his systemic approach to hospital quality by differentiating three areas: structure, processes, and outcomes. The structure refers to the organization of the institution and the characteristics of its human, physical and financial resources. The processes correspond to the content of care and to the way that care is executed. The outcomes represent the impact achieved with care, in terms of improvements in the health and well-being of individuals, groups or populations, as well as users' satisfaction with the services provided. In addition, this model proposes to address the quality attributes that characterize the health service in three dimensions: the human dimension, the technical dimension and the environmental dimension.

Ross et al. [4] group the characteristics of health quality in two major dimensions: technical quality, which seeks to guarantee the safety, effectiveness and usefulness of health actions, as well as timely, effective and safe care of the users of the services; and the quality perceived by the users themselves, taking into account the material, psychological, administrative and ethical conditions in which such actions are developed. This classification corresponds to what is understood by objective quality and subjective quality.

Nowadays, quality is evaluated through Hospital Accreditation models, excellence models such as the Malcolm Baldrige Quality Award of the United States and other national or regional Awards of Excellence such as the European model EFQM (European Foundation for Quality Management); or certified using ISO 9001 generic standard from the International Organization for Standardization (ISO) and its adaptations to the health sector [5]. External peer reviews are also used in some medical specialties. These same models can be used for 
internal self-evaluation and for quality management in the case of the ISO 9001 standard. The Ministries of Health in some countries use the Habilitation, Accreditation or Certification of Hospitals as a guarantee of compliance with minimum standards to provide the health service [6]. All different models are of great importance not only to improve the quality of services but also to secure and enhance the trust of external stakeholders such as patients, financiers and the state [7].

The objective of this study is to analyze the accreditation and ISO 9001 certification schemes of health institutions, as well as to identify the benefits of each of them, their similarities and differences.

\section{Methodology}

The theoretical research methods historical-logical and analysis-synthesis are used, starting with a review of the specialized literature, to know the main approaches related to the hospital quality and compare them to draw the conclusions regarding their similarities and differences.

\section{RESULTS}

\section{A. Conceptual framework}

According to the definitions of ISO/IEC 17000 [8], certification is the third-party attestation (issue of a statement, based on a decision following review, that fulfilment of specified requirements has been demonstrated) related to products, processes, systems or persons. Meanwhile, accreditation in the ISO scheme is always relative to a conformity assessment body, and it is the thirdparty attestation related to a conformity assessment body conveying formal demonstration of its competence to carry out specific conformity assessment tasks. The organizations authorized to certify compliance with the ISO 9001 standard are the certification bodies, which must be accredited by a recognized accreditation body.

Outside the ISO framework, accreditation is employed by sectors such as education and health. Specifically Hospital Accreditation is the formal statement by a recognized authority on the ability of a hospital to carry out specific tasks, according to predefined criteria. "A selfassessment and external peer assessment process used by health care organizations to accurately assess their level of performance in relation to established standards and to implement ways to continuously improve" [9].

Health care quality would be defined as "the optimal achievable result for each patient, the avoidance of physician induced (iatrogenic) complications, and attention to patient and family needs in a manner that is both cost effective and reasonably documented" [9]. This definition is not in contradiction with that given by the ISO 9000 standard [10], when it expresses that quality is the "degree to which a set of inherent characteristics of an object fulfils requirements". In the case of hospital quality, the "object" would be the health service and the requirements correspond to the attributes of the hospital quality, among them: patient safety, access, opportunity, efficacy, efficiency, patient suitability and acceptability $[11,12]$. These attributes are explicitly set out in hospital accreditation standards.

\section{B. Hospital Accreditation Programs}

The Joint Commission International (JCI) Accreditation Program is one of the most widely recognized all over the world [13]. JCI is the internationalization of the Joint Commission on Accreditation of Hospitals (JCAH), founded in the USA in 1951. Since 1987 this institution has evolved towards the Joint Commission on Accreditation of Healthcare Organizations (JCAHO), extending the accreditation model to other health institutions, in addition to hospitals. JCI was established in 1994 as a division of JCAHO with the goal of facilitating accreditation services worldwide in more than 90 countries. In 2013, JCI published the 5th edition of its international accreditation standards for hospitals, which include a section for academic medical centers. In the JCI standards all patientcentered hospital activities (Section II), those related to the management of the health institution (Section III) and those linked to the hospital as an academic medical center (Section IV), are conceptualized [14]. Quality improvement and patient safety are included in Section III.

In addition to the JCAHO program in the USA, a National Integrated Accreditation of Healthcare Organizations (NIAHO) program, by Det Norske Veritas (Norway), is being developed. This program is discussed below.

In Latin America since the early 1990s, Pan American Health Organization (PAHO), together with the Latin American Federation of Hospitals (FLH), have been working on defining the Manual of Hospital Accreditation for Latin America and the Caribbean, to provide guidelines for quality development of services.

Accreditations are generally carried out by non-state nonprofit entities, made up of representatives of all sectors that make up the health system, although in some countries, such as Cuba, this activity is assumed by the Ministry of Public Health [15].

In Colombia, the Decree No. 903 of 2014 updated the Single System of Health Accreditation - SUA (Spanish acronyms) -, to strengthen the implementation of higher 
standards of quality in health care [16]. The SUA is one of the components of the Mandatory System for Quality Assurance in Health and has been regulated since 2002 (Resolution 1774), and subsequently modified by Resolutions 1445 of 2006 and 123 of 2012. This Decree changes the unique accreditation body model (Instituto Colombiano de Normas Técnicas - Icontec) to the model of several accrediting entities which, in turn, must registered and accredited by The International Society for Quality Assurance in Healthcare (ISQUA), a worldwide reference for accrediting institutions.

According to the mentioned Decree No. 903, the SUA is the set of processes, procedures and tools of voluntary and periodic implementation by the institutions providing health services, health promoting entities, occupational risk management entities and health service providers institutions offering occupational health services, which are intended to verify the gradual compliance of quality levels above mandatory minimum requirements for health care under the direction of the state and the inspection, surveillance and control of the National Superintendence of Health.

The SUA is based on the Outpatient and Hospital Health Accreditation Manual [17], which applies to the health service provider institutions that offer outpatient, hospital or both services. In this Manual, the 158 standards are arranged as follows: in the first part the Group of Standards for the Assistance Process are set (section 7.1), in the second part appear the Group of Standards for the
Administrative Support to the care processes (sections 7.2 to 7.7 ) and the third section consisting of five quality improvement standards (section 7.8), which apply to all processes evaluated in both the health care and support to health care standards (Fig. 1).

\section{The ISO 9001 certification of health institutions}

ISO 9001 certifications are receiving increasingly greater interest from health institutions [18]. Specifically in the US, this increased attention has been accelerated since in 2008 the most influential insurance companies in the United States, the Centers for Medicare and Medicaid Services (CMS), approved Det Norske Veritas Healthcare (DNV Healthcare) as the new authority to judge Medicare payments, renewing this condition for six years in 2012 [19]. DNV Healthcare developed a National Integrated Accreditation of Healthcare Organizations (NIAHO) program, which is being used to accredit hospitals under the CMS Participation Conditions (CoPs) and combined the CoPs standards with the Requirements of ISO 9001: 2008. In 2013, DNV and Germanischer Lloyd (GL) merged.

In response, the Joint Commission announced in 2011 its relationship with Société Générale de Surveillance SA -SGS - (Switzerland) to offer ISO 9001 certification as part of the service it offers. In this way, the ISO 9001 system has become a model to follow to achieve hospital accreditation and maintain the standards necessary to preserve it [20].

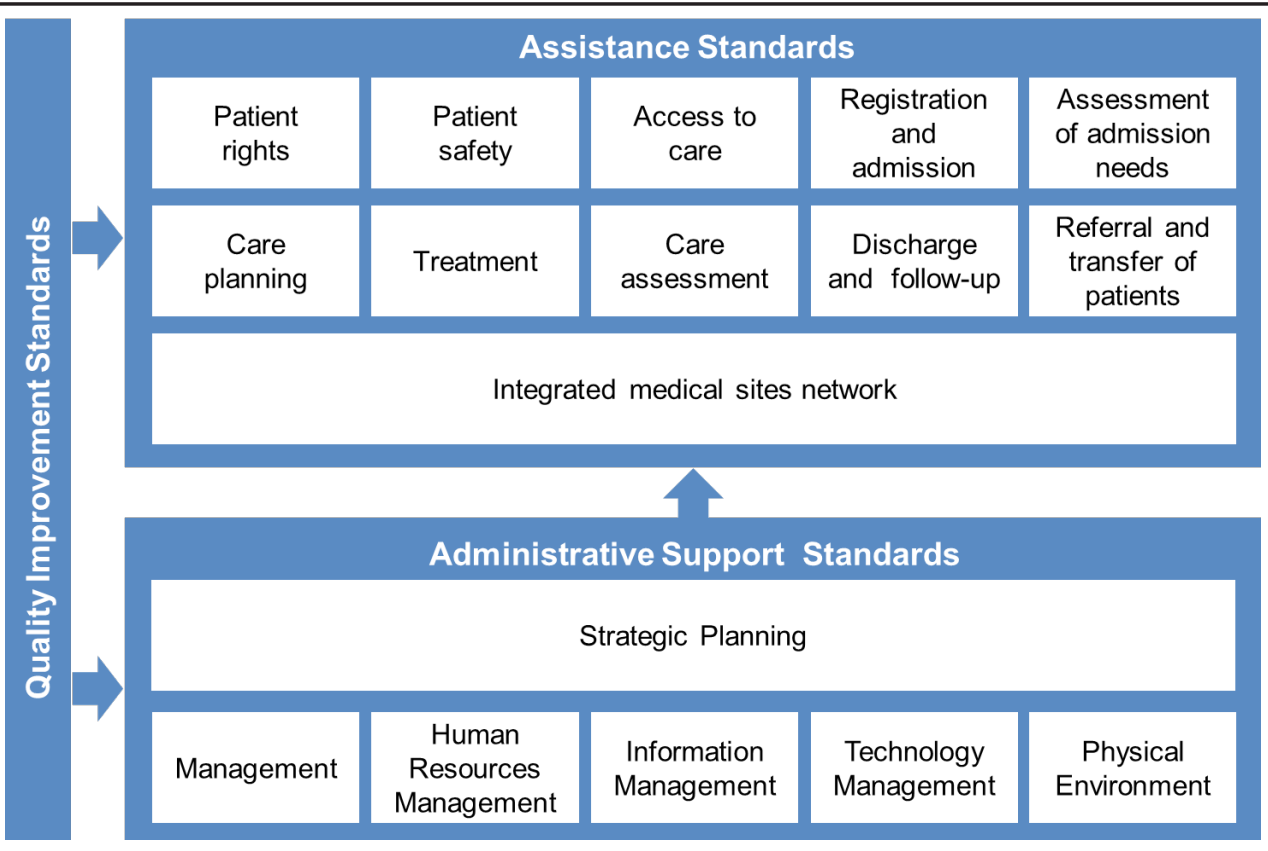

Fig. 1. Groups of standards in the Outpatient and Hospital Health Accreditation Manual in Colombia [17] 
The implementation of an ISO 9001 quality management system in a health institution provides confidence that the health service meets the needs and expectations of patients and other stakeholders, including established legal and regulatory requirements. It also gives management confidence that the expected quality is being achieved and is a tool for managing risks and improving performance. ISO 9001 certification provides external recognition that the organization complies with a number of internationally recognized requirements and good quality management practices.

With the ISO 9001 standard the health institution can obtain benefits such as:

- Well-defined areas of responsibility and greater knowledge of top management of how the institution works.

- Well-defined and documented procedures ensuring consistency of process results and minimizing errors.

- Continuous monitoring of processes and results, which allows corrective action at the moment the problems occur.

- Timely recording of events, as a source of organizational learning and improvement.

- Focus on risk management, which facilitates action to prevent quality flaws, including patient safety.

- Training employees to ensure their competence and knowledge of what to do in each situation and how to do it.

- Focus on improvement, which has a better service to patients.

- A better image for patients and society in general, creating new market opportunities.

Among other added values that the ISO 9001 implementation brings to the health institution, Nolan [22] includes internal audits and periodic reviews of the quality management system by management, monitoring and control of suppliers and customer satisfaction (patients and their families), taking corrective actions, better information, communication and motivation of employees and, finally, risk management and improvement.

ISO 9001: 2015 is based on seven quality management principles (customer focus; leadership; engagement of people; process approach; improvement; evidence-based decision making; relationship management), which allow managers to take a holistic view of the management of their organization, managing risks in a timely manner and using different quality improvement tools.

\section{Discussion}

There is no antagonism between ISO 9001 quality certification and hospital accreditation, on the contrary, they complement each other in the search for excellence in the delivery of health services. Both represent a thirdparty recognition of compliance with quality standards, strengthening the image of the health institution to society and contributing to the satisfaction of all stakeholders. Both tools are expected to provide patients with better quality health care. The joint application of both standards generates a favorable framework for the improvement of the organization's processes and for patients to receive a better service.

Both ISO 9001 certifications and hospital accreditations are fundamental instruments to improve the quality of the health service and to give credibility to the health institution in front of the society regarding the efficiency in its processes. Both guide efforts to improve patient safety and elevate the culture with respect to quality, including safety aspects [23].

However, there are some differences between these instruments. The hospital accreditations, being a sectoral mechanism, have a more technical character and are based on the best practices of the quality of the medical assistance, oriented directly to the attention of the patients. The ISO 9001 standard is more process-oriented and is designed to help organizations anticipate the risks in their management and take the necessary actions to manage them.

Hospital accreditation audits are performed by professionals who know the medical field in depth, while ISO 9000 standards are generic and audits of certification involve auditors of quality management systems, qualified to meet internationally agreed criteria by an organization Independent, in conjunction with medical experts. Another difference between accreditation and certification is that certification is the health institution that defines the scope of the same, while in the scope is defined by the accreditation standard itself. Many health institutions attest to ISO 9001 their support processes, such as the management of medical equipment and engineering systems.

Notwithstanding the undeniable advantages of ISO 9001 certification, some authors consider that the standard is difficult to understand and interpret in the health sector, and requires a significant effort in overtime of personnel, resources, external training courses and consulting and the own cost of the certification process [24]. It is noteworthy that these same authors, even after achieving ISO 9001:2000 certification of three hemodialysis centers, maintain nomenclature errors in their own accreditation and certification activities. 
To assist in the interpretation of the ISO 9000 standard in its application to health institutions, an International Workshop Agreement IWA 1 was approved in January 2001 on the proposal of the Healthcare Division of the Automotive Industry Action Group (AIAG) of the American Society for Quality (ASQ), as a result of a workshop sponsored by the Standards Council of Canada (SCC) and CSA International. A second revised edition of the IWA 1 was approved in 2005 [25]. This document was based on ISO 9004:2000 and it was withdrawn by ISO/ TMBG (Technical Management Board - groups) in 2014. However, a European technical report, based on this IWA, remains in force [26]. While these documents need to be reviewed in light of the new approaches and structure of ISO 9001:2015, they remain a useful reference material for the implementation of ISO 9001 in the health sector.

An ISO 9001:2015 quality management system is a suitable framework for incorporating the requirements of hospital accreditation programs and existing international methodologies for risk management in health institutions [23]. Both the generic standard ISO 31000:2009 [27] and the specific standards for the risk management of medical devices, ISO 14971:2007 [28], and patient safety, for example the Spanish standard UNE 179003:2013 [29]. Regarding the management of technological risk in the health sector, the authors coincide with Ana et al. [30] when they state that there is still much to be done in this field.

Health care institutions also can decided to certify their Risk Management System for Patient Safety. Such certification brings confidence to patients and to administration, improves clinical practices and patient safety, establishes monitoring of quality indicators and assures the control and compliance with legal and regulatory requirements. However, working in parallel involves efforts in repetitive work, loss of global vision and difficulty of analysis. The solution would be to integrate in a single system the requirements of the different regulations, based on an exhaustive analysis of them and an internal diagnosis of how the organization is meeting the different requirements and what remains to be done.

\section{Conclusion}

Instruments for external evaluation of hospitals and for their internal quality management analyzed are useful for improving the health services and they serve as tools to give confidence to the society regarding the quality level of institutions that make up national health systems. Both the accreditation standards and the ISO 9001 standard serve as strategic guidance to improve the quality of service including the patient safety.
Patient-centered accreditation standards guarantee the technical quality of the service while the ISO 9001 quality management system is the guarantor for the sustained success of the health organization. The joint implementation of both standards allows to achieving and maintaining the high quality standards of medical care required by society.

\section{REFERENCES}

[1]. H. Arce, "Quality Management in Health Care" (La Gestión de Calidad en Salud), Medicina y Sociedad, vol. 24, no. 3, pp. 163172,2001

[2]. G. Rencoret, "Medical Audit: Medical malpractice claims and liability. Quality management: risks and conflicts" (Auditoría médica: demandas y responsabilidad por negligencias médicas. gestión de calidad: riesgos y conflictos), Rev. Chil. Radiol., vol. 9, n. 3, pp. 157-160, 2003.

[3]. A. Donabedian, "The quality of care. How can it be assessed?", $J A M A$, vol. 260, no. 12, pp. 1743-1748, Sep 1988.

[4]. A. G. Ross, J. L. Zeballos and A. Infante. "Quality and Health Care Reform in Latin America and the Caribbean" (La calidad y la reforma del sector de la salud en América Latina y el Caribe), Pan Am J Public Health, vol. 8, no. 1/2, pp. 93-98, 2000.

[5]. C. D. Shaw, "External quality mechanisms for health care: summary of the ExPeRT project on visitatie, accreditation, EFQM and ISO assessment in European Union countries", Int. J. Qual. Health Care, vol. 12, no. 3, pp. 169-175, 2000

[6]. K. A. Zeribi and L. Marquez (2005). Approaches to Healthcare Quality Regulation in Latin America and the Caribbean: Regional Experiences and Challenges. LACHSR Report Number 68. Published for the U.S. Agency for International Development (USAID) by the Quality Assurance Project.

[7]. N. Klazinga, "Re-engineering trust: the adoption and adaption of four models for external quality assurance of health care services in western European health care systems", Int. J. Qual. Health Care, vol. 12, no. 3, pp. 183-189, 2000.

[8]. ISO/IEC 17000:2004. Conformity assessment -- Vocabulary and general principles

[9]. R. Agarwal. (2010, May 19). A Guideline for Quality Accreditation in Hospitals. [Online]. Available: http://www. qualitydigest.com/inside/twitter-ed/guidelinequality-accreditationhospitals.html

[10]. ISO 9000:2015. Quality management systems -- Fundamentals and vocabulary.

[11]. W. B. Runciman, J. A. H. Williamson, A. Deakin, K. A. Benveniste, K. Bannon and P. D. Hibbert, "An integrated framework for safety, quality and risk management: an information and incident management system based on a universal patient safety classification", Qual Saf Health Care, vol. 15, Suppl I, pp. i82-i90, 2006.

[12]. M. I. Ávalos, "Evaluation of quality in the primary attention of health care. Theoretic and methodologic considerations" (La evaluación de la calidad en la atención primaria a la salud. Consideraciones teóricas y metodológicas), Horizonte Sanitario, vol. 9, no. 1, pp. 10-15, 2010.

[13]. J. R. García Mata and J. I. Barrasa Villar. (2012). Quality Systems and Continuous Improvement - Quality Management Systems 
(Sistemas de Calidad y Mejora Continua - Sistemas de Gestión de Calidad). [Online]. pp. 132-164. Available: http://www.icsaragon. com/cursos/iacs/101/tema-3-2012.pdf.

[14]. Joint Commission International Accreditation Standards for Hospitals. $5^{\text {th }}$ Edition. 2013.

[15]. Y. Mejías Sánchez, N. Cabrera Cruz, M. M. Rodríguez Acosta, A. M.Toledo Fernández, M. V. Norabuena Canal, "Legal bases of quality in health services (Bases legales de la calidad en los servicios de salud), Rev. Cub. Salud Pub., vol. 39, no. 4, pp. 796803, 2013.

[16]. Ministry of Social Protection of Colombia (2014). ABC about the Single System of Health Accreditation (ABC sobre el Sistema Único de Acreditación en Salud). [Online]. Available: http:// www.saludcapital.gov.co/CTDLab/Publicaciones/ABC_Si stema_\%C3\%9Anico_de_Acreditaci\%C3\%B3n.pdf

[17]. Ministry of Social Protection of Colombia (October 2011), Outpatient and Hospital Health Accreditation Manual (Manual de Acreditación en Salud, Ambulatorio y Hospitalario.), 03. Bogotá, Colombia.

[18]. G. Lambert, "Breakthrough in US hospital accreditation looks set to accelerate ISO 9001 adoption in healthcare", ISO Management Systems, pp. 33-35, March-April 2009.

[19]. Y. Dror, "DNV GL Hospital Accreditation -Integrates Quality Management Standards, Improves Processes and Breaks Silos", presented at the Healthcare Education Assessment Training and Technology Conference HEATT, Orlando, FL, August 22-24, 2014.

[20]. I. R. Lazarus and M. W. Chapman, "ISO-Style" Healthcare: Designed to Keep Patients, Practitioners and Management Safe", Beckers Hospital Review. [Online]. September 26, 2013. Available: http://www.beckershospitalreview.com/hospitalmanagementadministration/iso-style-healthcare-designed-tokeep-patientspractitioners-and-management-safe.html.

[21]. ISO 9000:2015. Quality management systems - Requirements.

[22]. J. Nolan, "Would hospitals benefit from ISO 9001?" 9001 Academy. [Online]. July 21, 2015. Available: https://advisera.com/9001academy/blog/2015/07/21/ wouldhospitals-benefit-from-iso-9001/

[23]. R. Roque González, R. M. Guerra Bretaña, Y. Chaveco Salabarria, K. F. Ortiz Jaya and O. Vera Cabezas O. "A risk-based integrated management for patient safety and quality in healthcare services", presented at the VII Latin-American Congress of Biomedical Engineering - CLAIB 2016, October 2628, 2016. Bucaramanga, Colombia.

[24]. M. D. Arenas, M. T. Gil, J. J. Egea, A. E. Sirvent and A. Giménez, "Quality assurance and ISO 9001:2000 certification of an hemodialysis unity" (in Spanish), Nefrología, vol. 23, no. 1, pp.00, 2003.

[25]. ISO IWA 1:2005 Quality management systems -- Guidelines for process improvements in health service organizations.

[26]. UNE-CEN/TR 15592:2008 Health services - Quality management systems - Guide for the use of EN ISO 9004:2000 in health services for performance improvement.

[27]. ISO 31000:2009, Risk management - Principles and guidelines.

[28]. ISO 14971:2007 Medical devices -- Application of risk management to medical devices

[29]. UNE 179003:2013 Health services. Risk management for patient safety.
[30]. C. C. Ana, E. M. Nelson and B. M. Juan, "Technology Surveillance for Technological Risk Management in the Health Sector associated with the ISO 31000 standard" (Vigilancia Tecnológica para la Gestión del Riesgo Tecnológico en el Sector Salud asociado a la norma ISO 31000), Revista Ingeniería Biomédica, vol. 9, no. 18, pp. 117-125, 2015. 